\title{
Noonomy as the Material Basis for a Prospective Humanitarian Model of Public Order
}

\author{
Sergey Bodrunov
}

Citation: Bodrunov, S. Noonomy as the Material Basis for a Prospective Humanitarian Model of Public Order. Sustainability 2021, 13, 1454. https:// doi.org/10.3390/su13031454

Received: 17 December 2020

Accepted: 25 January 2021

Published: 30 January 2021

Publisher's Note: MDPI stays neutral with regard to jurisdictional claims in published maps and institutional affiliations.

Copyright: (C) 2021 by the author. Licensee MDPI, Basel, Switzerland. This article is an open access article distributed under the terms and conditions of the Creative Commons Attribution (CC BY) license (https:// creativecommons.org/licenses/by/ $4.0 /)$.
S.Y. Witte Institute for New Industrial Development, 197101 St. Petersburg, Russia; inir@inir.ru

\begin{abstract}
The development of the modern technological revolution and evidence of a deepening civilization crisis make us pose the question about the prospects of the social and economic transformation of the modern society under the influence of certain factors. S. Bodrunov approaches the resolution of this problem from the historical perspective on public development. He relies on methodology of the classical political economy and considers changes in the material basis of production as the main drivers of upcoming changes. Technological shifts lead to changes in the content of human activity and opportunities for the satisfaction of human wants. They also result in a gradual removal of humans from immediate production and cause shifts in the entire social structure. The author shows that the next stage in the development of the modern civilization will be the formation of a new type of public order-the New Industrial Society of the Second Generation (NIS.2), which stipulates gradual creation of prerequisites for transitioning from the economy to the noonomy. The noonomy constitutes a non-economic way of satisfying humans' reasonable wants. It will serve as the material foundation for forming and ensuring the functionality of the noosociety. The article determines that humanitarian culture as a timeless value exerts crucial influence on the positive development of transformation processes considered under the theory of noonomy.
\end{abstract}

Keywords: New Industrial Society of the Second Generation (NIS.2); noonomy; noosociety; technological revolution; material production; humanitarian values

\section{Introduction}

Two worldwide economic crises of the twenty first century and the pandemic that exacerbated the second crisis made scholars of civilizational issues, as well as politicians and experts, including speakers of the World Economic Forum, perceive the upcoming colossal transformation of the global public order and bring up the need to introduce major changes in socioeconomic institutions and politics and find a way to respond to the challenges that accompany this transformation and increasingly escalating global problems. But the task at hand is not limited to institutional and political reforms. It is much deeper and broader: on the one hand, there is an objective urgent need to transition to a new type of public development; on the other hand, for the first time in the history of human civilization we have created the material capability for such transition that would negate and inherit the achievements of what Karl Marx labeled "an economic transformation" 150 years ago, i.e., the transition to such public order that would not only fulfill Marx's forecast about stepping "to the side of the production process," but also implement many other trends that showed their true promise only in the beginning of this century. It is this objective process that constitutes the essence of the transition to the noosocietal public formation considered herein, its mechanism for the satisfaction of wants being referred to as 'the noonomy' - unlike the economy which serves as the mechanism for wants satisfaction in an 'economic' society.

It would be both commonplace and inaccurate to say that the modern society is on the verge of changes. Our society has already been dragged into profound changes which are leading us to some future with vague and unclear contours. Social scientists have time 
and again tried to draw an image of the future, but right now we encounter a theoretical vacuum in this matter. The latest attempts at creating a broad theoretical concept that would explain the ongoing and upcoming changes have been made by proponents of the idea of postindustrial society. In order to analyze the main concepts developed under this train of thought, we would require a lot more than an article or even a whole book. In this case, however, that is not necessary, so I will just make a reference to the best known book by Daniel Bell [1], the patriarch of postindustrialism.

The idea of the postindustrial society relied on a number of rather obvious facts (the list of such facts and trends can be found in Alvin Toffler's work [2]). Some prognoses made under the aegis of the idea of the postindustrial society, e.g., a dramatic increase in the role of knowledge and information in modern production [3], have been confirmed. Nevertheless, the idea of the postindustrial society has not been taken up as a scientific platform for understanding the future, albeit the term 'postindustrial society' has become quite popular.

The idea was criticized at its inception, e.g., by Robert Heilbroner [4,5]. Subsequently, postindustrial illusions have been repeatedly criticized [6] as noxious and leading to the slowdown of economic growth and stagnation of income for the majority of the population. A broad review of such criticisms is available in a modern four-volume publication on postindustrial theories (Vol. 1 and 2, Sections 3 and 4) [7].

Even though those who elaborated on the concepts of the postindustrial society have discussed changes in technologies and the content of labor, these changes have been studied only pertaining to a small number of segments and professions. As for the conclusion that the society as a whole is becoming postindustrial, it rests on a dramatic decrease in the share of industry in the GDP (gross domestic product) and in employment and a congruous increase in the share of the service sector. Still, in order to understand the actual role of technological shifts in production, we should not confine our analysis to changes in the share of industrial segments in the GDP and employment structure but also pay attention to actual shifts in the content of technological processes and the nature of human activity.

The study of economic patterns in the development of technologies that goes back to Joseph Schumpeter has engendered the concept of a change in technological modes. According to Joseph Schumpeter, innovative activities of entrepreneurs who perform technological updating of production in order to obtain competitive advantages constitute the main driver of such change. Still, Schumpeter believed that such updating of technologies did not progress evenly over time. Schumpeter referred to new technology complexes that developed during spikes in innovative activity as 'clusters' (bunches) [8].

In 1975, Gerhard Mensch, a scholar from West Germany, confirmed this conclusion and showed that periods of technological stagnation characterized by the prevalence of incremental or even pseudo-innovations were succeeded by periods of implementation of revolutionary (baseline) technological solutions [9]. He also used the term 'clusters' to refer to complexes of basic innovations that result in the industry's transition to a new development level. In 1970-1980, a British economist Christopher Freeman introduced the concept of a 'technological system' and supported the concept of 'techno-economic paradigm', which was formulated by his student Carlota Perez [10-12].

The term 'technological mode', which is used in the Russian economic science, is similar to the concepts of the 'waves of innovation', 'techno-economic paradigm' and 'technological system. This term was first suggested in 1986 by D. S. L'vov and S. Y. Glazyev [13]. According to the definition given by S. Y. Glazyev, the technological mode is a sustainable holistic structure which comprises a full cycle from the extraction and processing of primary resources to the production of end products that correspond to the type of public consumption.

We are currently witnessing broad expansion of the fifth technological mode and the emergence and development of the sixth mode. The consequence of the ongoing transition in technological modes is the Fourth Industrial Revolution [14], which leads to dramatic shifts resulting in an increase in knowledge intensive production and products' 
knowledge intensity [15], as well as the removal of humans from the immediate production process. That does not signify the emergence of an army of 'superfluous humans', but reflects a change in the nature of human activity, i.e., the transition from hands-on labor to intellectual and creative activity.

Along with the development of technologies and a change in the content of human activity, we are seeing changes in public relations. One symptom of such changes is the evolution of ownership relations. Economic theory has already taken up the relatively recent trend which stipulates the development of the sharing economy based on consumers' desire to abandon property ownership and their preference for the role of temporary users. Yohai Benkler [16] and Russell Belk [17] were among the first scholars who noted this phenomenon. They concluded that the sharing economy was characterized by a significant influence of social and cultural factors along with traditional market motives of human behavior.

The importance of social and cultural factors of human behavior becomes particular prominent if we account both for new opportunities and new risks inherent in ongoing technological changes. New technologies are creating much broader opportunities for the satisfaction of human wants [18] (pp. 261-262), but they also carry dramatically higher risks. The satisfaction of wants may turn into thoughtless inflation of consumption powered by the pursuit of simulative goods. As early as in the beginning of the twentieth century, Thorstein Veblen [19] noted that real consumption goals were being substituted with symbols, but this phenomenon has gained a much more profound meaning and become much more widespread in the modern era. Jean Baudrillard [20,21] and Fredric Jameson [22] analyzed the nature of simulacra and simulative goods in their work. Such unchecked augmentation in the volume of consumed goods leads to the destruction of environmental balance, which is reflected in exceeding the ecosystem's ability to renew consumed resources [23].

The economic logic of human behavior leads to further depletion of resources and careless interference with the environment and the very human nature. Opportunities for such interference are increasing manifold with the development of modern technologies. These dangers underlie the need to abandon economic rationality and transition to a new rationality that would be based on the criteria of reasonable saturation of wants as determined not by economic profit, but by cultural norms. Ultimately, we must transition from the economy to the noonomy, i.e., a non-economic method of production and satisfaction of wants [24]. Under the noonomy, the criterion for assessing the efficiency of productive activity shall be not higher production volumes, but reasonable determination of wants per se and the requisite level of their saturation that can create opportunities for personal development. As for production, it will be increasingly serviced by the relatively autonomous technosphere, and humans will assume creative functions, such as acquisition of knowledge, and using it as the foundation to ensure technological progress and the functioning of the technosphere.

\section{Materials and Methods}

When studying the consequences of technological development from the perspective of its effect on the social structure, we should apply methodological approaches that shed light on the role of material production, its product, industrial production, and their place in the socioeconomic structure of the society. The starting point for understanding the prospects for the evolution of the social structure is to understand that material production lies at the core of human society's livelihood and, accordingly, changes in material production determine the development of the society.

In this regard, it is important to consider all components of production: specific characteristics of the technological process, the nature of the product of production, content of labor, and formats for production organization. Only combined, these elements allow for the development of a holistic understanding of the shifts that occur in production. 
In its historical development, the material and technological foundation of the economy goes through two main stages: pre-industrial and industrial production. Of course, we can delineate various steps within these two stages, but, fundamentally, no other options (except for these two stages) can be identified in the development of material production. Hypothetical 'postindustrial' production has not yet come to pass. Despite the prevailing share of the service sector, the modern economy rests firmly on its industrial material production.

In particular, industrial production has characteristics that set it apart from preindustrial production. Some of these characteristics are as follows:

- use of complex means of production rather than manual labor;

- reliance on universal man-made energy sources (various steam engines, internal combustion engines, electrical motors, jet engines, etc.) rather than on natural energy sources (human and animal muscle strength, natural water and wind power);

- $\quad$ use of technologies primarily based on scientific knowledge that makes it possible to transform various natural processes into human-controlled and human-directed technological processes rather than on empirical production experience;

- facilities allowing both for mass production of standardized products and their adaptation to the needs of individual consumers.

Therefore, the stance that I clearly pursue in the theory of noonomy is the recognition of the fact that industry definitely constitutes the production and technological core in the modern economy. Industrial production provides the necessary economic conditions for the development of all other sectors of the economy-construction, the agricultural sector and service industries in aggregate- by supplying them with various materials, machinery and equipment, and by developing technological processes.

Indeed, over the past 250 years, industrial evolution has, to a great extent, determined shifts in the society's socioeconomic formation. This development transpires by transitioning from one technological mode to another. That is why a method for assessing the evolution of the public order must account for special characteristics of technological modes and patterns in their development and shifts.

Transitioning from one stage in societal development to another is related to urgent resolution of contradictions accumulated at the previous stage and involves locating and using opportunities for the resolution of such contradictions that are formed at this stage. At the same time, it is important that we heed those new public phenomena that are symptomatic of the emergence of new public relations at the current development stage. The study of these relations allows for forecasting the contours of the future public order.

\section{Results}

\subsection{The Importance of Industry}

Aggregate data indicate that the role of industry in the global economy is much more prominent than the official digits of its share in production of GDP. It is common knowledge that industry has played the most important role in ensuring growth for developed and medium developed countries [25]. This conclusion is supported by a number of studies on specific countries and regions $[26,27]$.

Even though modern segments of the service sector can also promote acceleration of economic growth, the role of industry remains critical for creating jobs and generating domestic demand in the economy [28]. Industry ensures the development of exports and relatively higher salaries. Its development leads to the growth of employment in other segments [29].

But the critical role of industry's development applies not only to developing and medium developed countries. For example, products manufactured by industrial segments account for approximately $80 \%$ of the global turnover. In the U.S. economy, industry demonstrates an extremely high multiplicative effect, where each $\$ 1$ of industrial spending yields $\$ 1.32$ of value added in other segments. Industry accounts for more than $75 \%$ of private R\&D (research and development) spending in the U.S. [30]. 
Studies on the role of industry in economic development of EU countries arrive at similar conclusions and even point out the need to increase the share of industry in the GDP of EU members [31] (p. 140). The majority of EU countries are currently seeing an increase in employment in the processing industry [32].

Such economic policy of reindustrialization is based not only on fundamental research [33-35] but also on obvious empirical facts. The processing industry accounts for more than half of European exports and approximately $65 \%$ of R\&D expenses. Moreover, it provides 52 million jobs. In 2016, direct employment in the European processing industry constituted 32.076 million people, and that generated another 20.826 million jobs in linked segments [36].

\subsection{Technological Revolution and Its Consequences}

Industry also plays a key role from the perspective of new technologies' development. We are currently observing the transition from the fifth technological mode-which was formed in the 1950s-1980s and claimed the dominant position, for now only in the economy of most developed countries - to the sixth mode. Scholarly premises for this mode were developed in the 1970s-1990s, whereas applied technologies of the sixth mode started to spread in the twenty first century. The share of such technologies is not large so far, but they are showing a rather broad promise. The nature of these technologies is such that their wide application brings the modern economy not only to a change in technological modes but also to the verge of a new technological revolution.

The most important outcome of developing technologies of the sixth technological mode is the formation of Industry 4.0 [37], its main element being the so-called smart factories. In their operations, smart factories and Industry 4.0 as a whole rely on information and communications technologies, including the Internet of Things, or, rather, the Industrial Internet of Things [38], which allows for the interaction of autonomous technical devices with each other and for human control over them. In order to ensure such control, we are widely implementing built-in sensors and systems for processing big data obtained from them.

As for production technologies, they are beginning the transition from subtractive technologies - based on trimming, grinding and cutting of part blank - to additive technologies based on addition or layering of base materials [39].

An example of an additive technology that is rapidly gaining popularity is 3D printing, which builds from primary materials layer by layer using three-dimensional computer models of an end product. In 2017, worldwide sales of 3D printers exceeded 400 thousand units [40]. In 2018, the amount of sold 3D printer units decreased by several percent, but the sales value increased by $27 \%$, and suppliers' profits went up by $44 \%$. The segment of rather basic desktop 3D printers designed for domestic use reported a decrease in sales, while the sales of industrial and designer units have been growing and now account for about $70 \%$ of the market [41].

Naturally, the development of the sixth technological mode is not limited to additive technologies. The synthesis of nano-, bio-, information and cognitive technologies (the so-called NBIC convergence, i.e., unification of nanotechnology, biotechnology, information technologies and cognitive science) also shows a lot of promise [42]. Lately, NBIC has grown to include social sciences and transformed into NBICS [43]. In my opinion, it accurately captures the trend of this process and, in fact, the vector of our civilizational development.

A spike in the application of new knowledge is becoming a distinctive feature of the new technological revolution. The share of knowledge in production costs is growing, whereas the relative share of material resources is decreasing.

And we are seeing that the sixth technological mode leads, to say the least, to a sharp decrease in humans' immediate involvement in material conversion of primary resources. Humans are increasingly assuming the functions of goal-setting and control, while immediate handling of natural matter is performed by autonomous technetic beings. 
Widespread implementation of industrial robots is but the first step on this path. Surgical robots are no longer uncommon; robot drivers cruise the roads; and artificial intelligence is increasingly replacing human interaction with clients of commercial and banking firms.

Let us consider one example of a robotic center that comprises modern information and telecommunications technologies, robotics itself, and 3D printing-a novel product Olli [44]. It is marketed by Local Motors, a U.S. company which introduced an unmanned passenger bus manufactured by an integrating information system, made from parts that were almost completely produced on a 3D printer and assembled by an automatic production line [45]. Material costs (compared against the use of traditional materials) and the cost of labor were reduced manifold. The breakdown of the full production cycle is as follows: production of all parts took $10 \mathrm{~h}$; automatic assembly was completed in $1 \mathrm{~h}$; software download and testing of separate systems and the finished product also took $1 \mathrm{~h}$, so the overall production time constituted just half a day of continuous work that required virtually no human involvement.

To ensure that passengers are comfortable with using this product that initially seemed rather unusual, its makers reached out to IBM, which immediately suggested the IBMWatson system [46]. Figuratively speaking, it is a talking guide that can answer any queries (in a number of widely used languages) vocalized on the bus, such as: travel time, bus stop closest to destination, expected delay time due to traffic jams, emergency numbers, etc. Thus, Local Motors manufactured a robot-bus. Will passengers have the same experience compared to riding a regular bus driven by an attentive driver? No! Passengers will have an even better experience (otherwise, the new product will not be popular in the competitive market!) because multimedia services installed on the bus will provide them with an opportunity to chat, get a consultation, obtain travel information, use Wi-Fi, watch $\mathrm{TV}$, work, learn, have fun, etc.

This example comprises all three paradigmatic technology components (which change the paradigm of the traditional industry and all its elements) of the upcoming new industrial revolution, i.e., digitalization, additive printing, and robotization.

The Internet of Things and similar technologies entail essential changes in approaches to many traditional areas of economic activity ranging from retail and the service industry to construction (on a side note: in turn, they lay strong foundation for future innovations). At the same time, synergistic potential inherent in modern technologies does not decrease, but increases upon implementation. One striking example is the development of information technologies, where the higher efficiency of hardware enhances software efficiency, while the improvement of software increases hardware capacity.

Application of knowledge intensive technologies results in fundamental changes that also occur in such component of the industrial process as industrial engineering. These changes include the improvement of production management systems, conversion of product design to 3D modeling, optimization of transportation/material/information/etc., flows and automation/internetization of management solutions-when systems administrators become factory administrators!—and much more.

The use of self-learning artificial intelligence (AI) systems leads to cognitive technologies penetrating, under the sixth technological mode, into areas which used to have no alternative to human labor. Today, AI systems are capable of searching, accumulating, sorting and comparing information that provide the foundation for decision-making. It is cognitive technologies that, through using advances in biotechnology and information and communications technologies, allow for direct human interaction with unmanned technological processes (human-machine interfaces, human-machine systems, human-machine networks) [47]. This foundation gives a fresh impetus to the production of robotics, which becomes more flexible, more adaptable, and more productive.

The emergence of new technologies changes not only the very technological processes but also all elements of material production, i.e., the nature of end products, content of labor, and methods of production organization. That is why it is important to speak of not just technological but also of a large and complex industrial revolution. 


\subsection{New Stage in the Development of Industrial Society}

If we perceive the previous industrial era, which unraveled as J.K. Galbraith was writing his famous book The New Industrial State [48], as a new industrial society of the first generation, then we are nearing the transition to the second generation. As we have stated and substantiated in our core works $[49,50]$, the upcoming industrial revolution prepares us for a soon-to-come new type and new generation of the industrial society (we refer to it as the New Industrial Society of the Second Generation, or the NIS.2) and further for the transformation of the current economic development paradigm into the noonomy, which stipulates a more socialized type of production and distribution of public goods.

A change in the main economic resource serves as the core distinction of this generation of industrial production. The role of the main resource and source of development is passing on to knowledge, i.e., humans' scientific cognition of the world around them.

Since the last third of the twentieth century, the human civilization has been gradually moving towards the NIS.2, i.e., a system of economic relations and institutions wherein the main role is assumed by high-tech knowledge intensive material production. The first step in the transition to the NIS.2 is a decisive reindustrialization of the economy that rests on approaches and theoretical views that are dramatically different from postulates expressed in liberal narratives.

In an attempt to overcome them, scholars keep introducing new ideas and theories, but they prove inefficient. Their recommendations do not work because they rely on the erroneous postindustrial paradigm. This situation provides yet another proof of the fact that it is material production, albeit modified, that remains the foundation of the future economic and public order.

On the other hand, we are starting to perceive that today economic growth as such is not that important for us, and this idea is gaining universal support around the globe. What is important is the structure and quality of economic growth, which implies technological, technical and scientific progress and knowledge intensity of the public product that comprises the GDP. But the progress of technologies per se is neither the ultimate goal nor the supreme value in the modern world. It is an operational goal, so to say, albeit a very important one. So, what is more important? Humans, their lives, development and wellbeing serve as such ultimate higher purpose and value from the humanitarian perspective.

Clearly, movement towards the noonomy is a long historical transition. But it is important to emphasize that, in the near future, changes which lead to the transition to the NIS.2 stage, and, ultimately, the transition from the economy to the noonomy will bring about changes in economic relations and in the nature of ownership relations endemic to this new generation of the industrial society. Can we discern manifestations of characteristics of the society's new state during the upcoming transformation of global public development?

\subsection{Evolution of Ownership Relations}

One of the most significant manifestations of the transition to a new paradigm is the dilution of conventional and customary ownership relations, including private ownership that serves as the pillar of the existing market, capitalist model of both the economy and the society. Such trends can be observed even at the modern stage in societal development before the transition to the NIS.2. Ownership relations, especially as they pertain to private ownership, were supposed to secure owners' uncontested rights to hold, use, and allocate economic resources. But the evolution of economic relations has long since led to possessions' encrustation with various encumbrances meant to ensure owner's social accountability.

For example, various easements (right of way, right of access to water sources, right of livestock crossing, right of access to coastal areas, right to lay the service lines, etc.) provide third persons with an opportunity to use, within certain limits, land lots that they do not own or possess. There are numerous restrictions and encumbrances of the 
rights of ownership that pertain to construction, transportation and industrial activity and are related to ensuring compliance with safety regulations, upholding certain quality standards, observing environmental regulations, etc.

We should pay special attention to the evolution of intellectual property relations because they regulate the economic turnover of knowledge-the main resource of modern production. In this segment, we see the emergence of such phenomena as crowdsourcing, Wikinomics, free software, open source, copyleft, etc., that promote free access to intellectual resources. At the same time, there is rather stiff competition for intellectual property enclosure. This situation correlates to two trends in the development of ownership relations that can be observed in the modern economic system: (1) preservation of existing relations and (2) dilution of ownership rights to the point of complete disavowal of ownership.

And that does not just apply to knowledge ownership. Today, we can observe the removal of appropriation, allocation and even use relations (in a classical political economy sense of the phenomenon) through developing formats for joint performance of these functions by a potentially unlimited number of actors. In other words, we are witnessing what the latest global economic literature refers to using the peculiar term 'disavowal of ownership'.

It covers various formats of co-ownership, sharing, co-consumption, co-working, coliving, etc., integrated within the sharing economy. An owner may temporarily relinquish the use of possessions or property and transfer the right of usage to another person through such mechanisms as renting, leasing and various types of sharing (coworking, car sharing, kick sharing, bike sharing, time-sharing, food sharing, etc.).

Even though the sharing economy has gone mostly unnoticed until 2010, the survey of 30,000 consumers in 60 countries, which was conducted in Q3 2013, demonstrated significant willingness to participate in the sharing economy (see Figure 1).

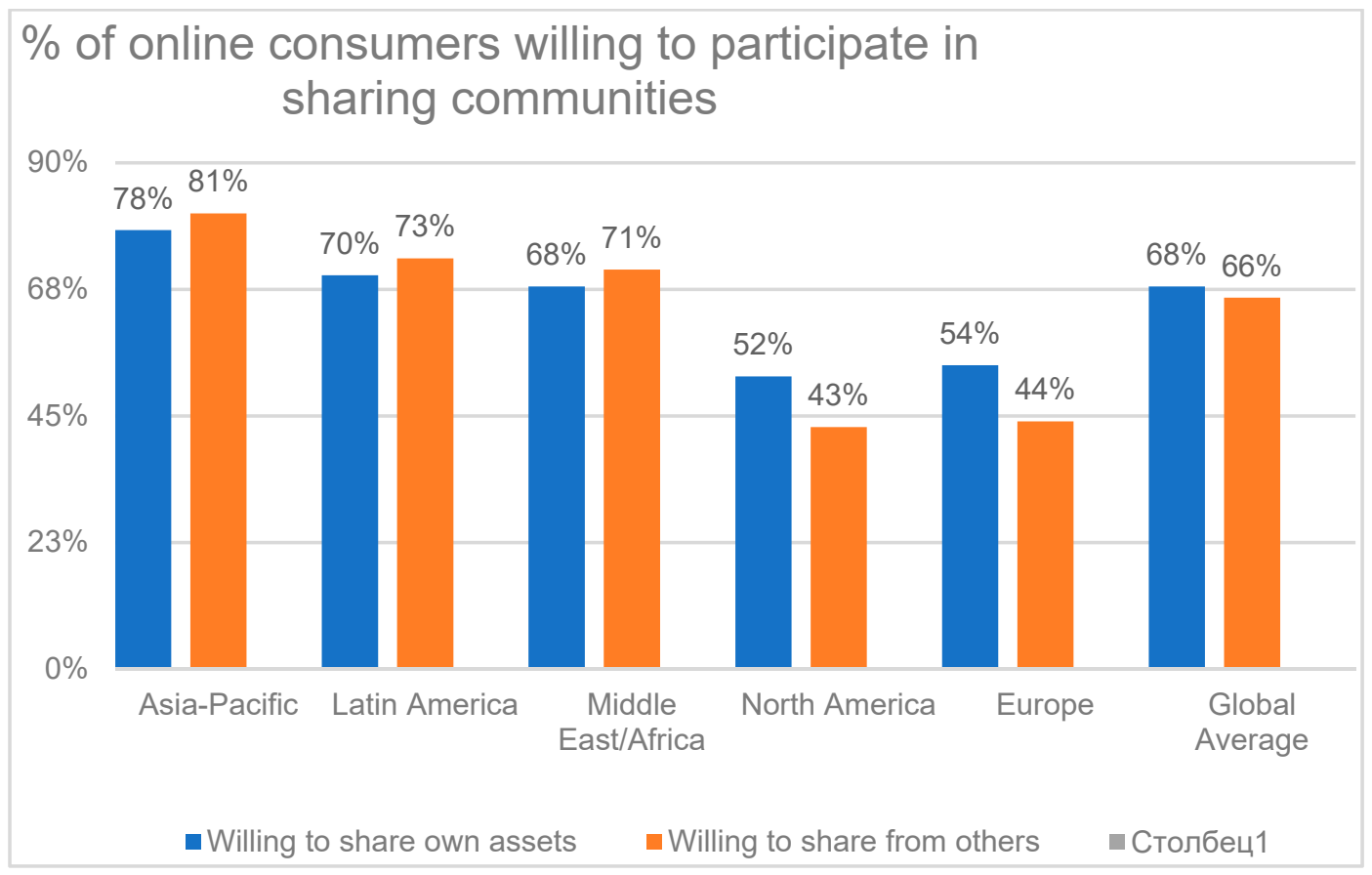

Figure 1. Percent (\%) of online consumers willing to participate in sharing communities (2013). Source: Reference [51].

Car sharing holds the largest share in the sharing economy, and the growth of this segment serves as one of the most important indicators of the entire sector's development (see Figure 2). The growth of car sharing has exceeded the most optimistic forecasts. A forecast from August 2016 predicted that, in 2025, the number of car sharing users would reach 36 million. But their number already exceeded 50 million back in 2018 [52]! 


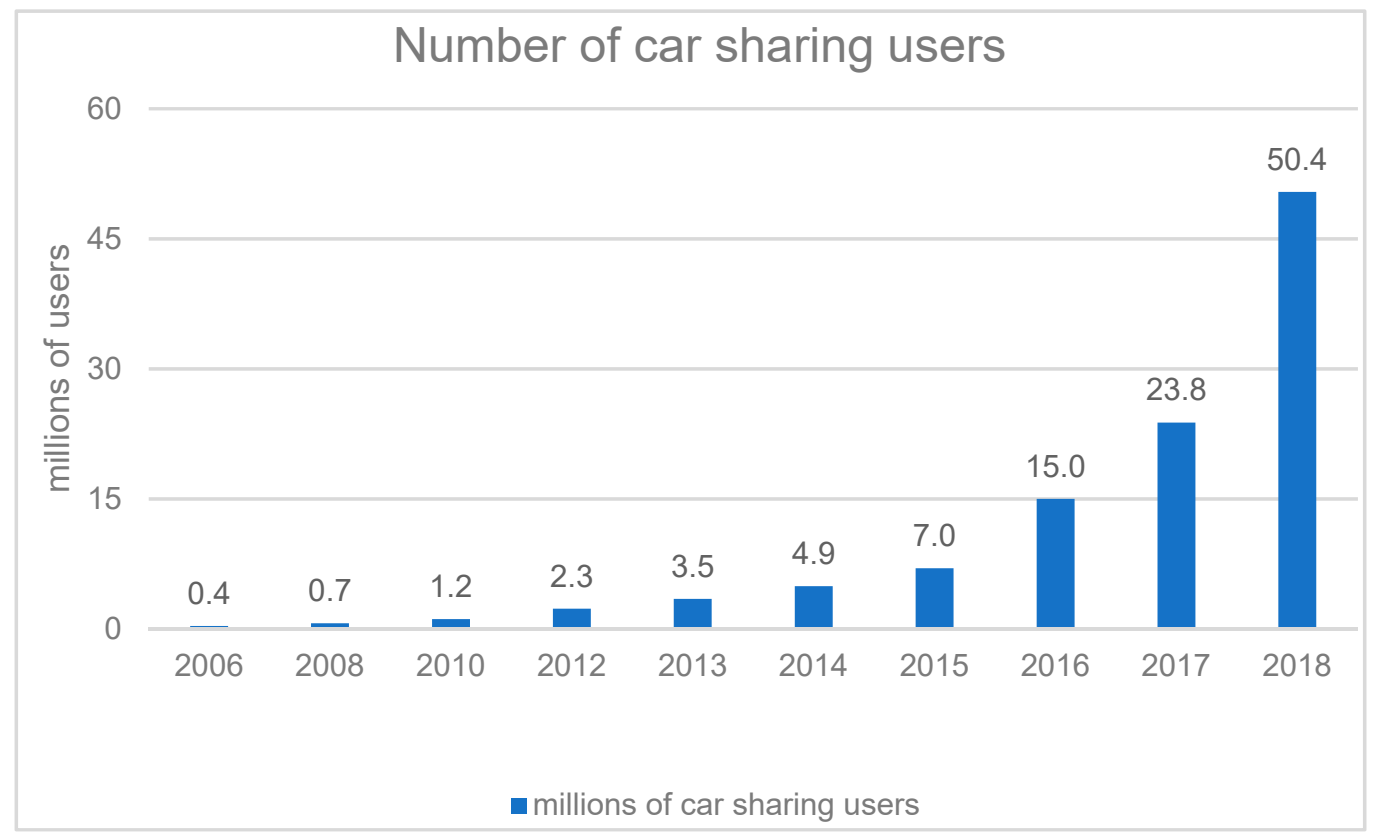

Figure 2. Number of car sharing users from 2006 to 2018. Sources: References [52-55].

The size of the sharing economy market constitutes hundreds of billions of U.S. dollars per year. In China alone, according to iiMedia Research consultancy report, the market size of the sharing economy reached \$1.05 trillion in 2019 and is expected to exceed \$1.28 trillion in 2020 [56]. Thus, the share of the sharing economy came close to accounting for $8 \%$ of China's GDP.

Such quick rise of the sharing economy is supported by considerable investment. Business took note of people's increasing willingness to use without owning, so investment in the sharing economy has seen rapid growth (see Figure 3).

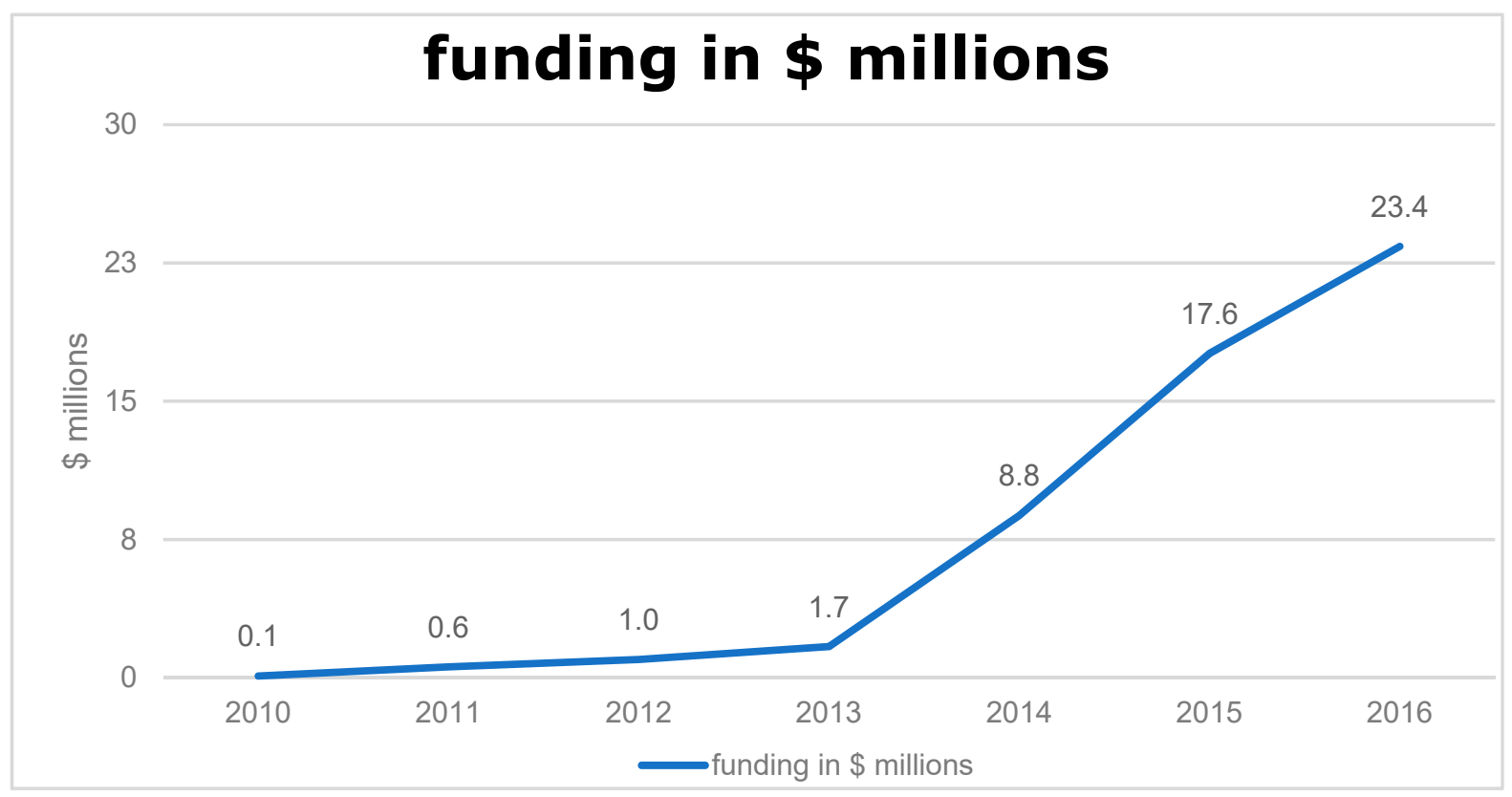

Figure 3. Cumulative funding for asset-sharing startups, 2010-2016. Source: Reference [57].

Let us point out that the development of the sharing economy demonstrates combinations of various motives, which definitely include economic rationality based on financial 
considerations. Joint use of things, as in the case of well-known car sharing that is popular with people who live in large cities and use cars irregularly, is economically rational. Under the economic society, that definitely provides an incentive to expand the influence of this sector. On the other hand, it objectively leads to the so-called 'thinning' of ownership, its meaning and value and-provisionally-to it no longer being a defining factor for the development of ways for satisfying human wants.

At the same time, numerous empirical studies prove the existence of non-monetary, non-economic public values and motives that constitute an important component of new relations. That is also a clear sign of movement towards the noonomy, for progress towards the noonomy as the foundation of a prospective format of public order suggests proactive development of non-economic, including non-monetary, motivation. And, in this case, we are seeing real social practices that are evolving in this particular direction.

We are observing increasingly active formation of alternative, new and associated formats of production and consumption. And these formats are built, first and foremost, on new technologies for working with information, on knowledge technologies that penetrate into the fabric of social and economic relations and reshape not only material production but also the entire society. We must acknowledge visible changes in public conscience and the system of social values and preferences. Of course, we are not inclined to idealize and exaggerate the scope of these changes. They are still weak. But we can trace the trend of their conversion into the mainstream. Private property, a staple of the market paradigm, is falling apart or 'diluting', to be more precise. In some cases, it becomes redundant, and its institution is no longer perceived as fundamental and, quote unquote, 'sacred'.

We are seeing stronger motivation to disavow ownership in favor of other-simpler, cheaper and more progressive from the social, environmental and ethical perspectivesmore humanitarian ways of using goods as opposed to their private ownership. As Bardi and Eckhard point out, "[i]nstead of buying and owning things, consumers want access to goods and prefer to pay for the experience of temporarily accessing them" [58] (p. 881).

Thus, the development of the sharing economy is a phenomenon that constitutes a major change in the structure of the economy which overlaps with the change in the nature of ownership relations, as we transition to a new quality of public development characterized by a humanitarian focus - the NIS.2 and noonomy. From this standpoint, the sharing economy de facto serves as a transitional economic formation that combines both applied economic and non-economic drivers of human activity.

\subsection{Escalation of Civilizational Risks}

Still, new technologies not only open new opportunities but also generate considerable potential risks and threats. The growth of technological capabilities for the satisfaction of wants presents the humanity with a dilemma of its civilizational development. We often say that an environmental crisis is looming because we littered the whole world with plastic, nature creates mutant animals, dozens and hundreds of species disappear every day, and we see the emergence of technetic creatures that spawn at a pace much faster than natural. The reason is that the number of the so-called technetic beings (if we use the terminology of geobiocenosis to refer to creatures inhabiting the technological cenoses) is growing quickly.

Those elements of technocenosis that we label the 'technetic beings', which certainly exist and occupy a certain place in our space, are increasingly gaining ground. They are driving out natural beings, and today their creators—humans—have already become a significant geological, not to mention biological, force. According to geologists, the total volume of everything that humans have created over five thousand years of their existence, also known as the weight of the technosphere, i.e., everything created by humans over their history with the help of technology, constitutes 30 trillion tons (Table 1), whereas, according to biologists, over 4.5 billion years of the Earth's existence, the weight of biome, i.e., everything created by nature, constitutes approximately about 2.5 trillion tons [59] (p. 12). 
Table 1. Approximate mass of the major components of the physical technosphere, arranged in order of descending mass (where $1 \mathrm{Tt}=10^{12}$ metric tonnes).

\begin{tabular}{cccccc}
\hline Component & $\begin{array}{c}\text { Area } \\
\left(\mathbf{1 0}^{\mathbf{6}} \mathbf{~ k m}^{\mathbf{2}} \mathbf{)}\right.\end{array}$ & $\begin{array}{c}\text { Thickness } \\
\mathbf{( \mathbf { c m } )}\end{array}$ & $\begin{array}{c}\text { Density } \\
\mathbf{( g / \mathbf { c m } ^ { \mathbf { 3 } } )}\end{array}$ & $\begin{array}{c}\text { Mass } \\
\mathbf{( T t )}\end{array}$ & $\begin{array}{c}\text { Percent } \\
\mathbf{( \% )}\end{array}$ \\
\hline Urban areas & 3.70 & 200 & 1.50 & 11.10 & 36.9 \\
Rural housing & 4.20 & 100 & 1.50 & 6.30 & 20.9 \\
Pasture & 33.50 & 10 & 1.50 & 5.03 & 16.7 \\
Cropland & 16.70 & 15 & 1.50 & 3.76 & 12.5 \\
Trawled sea floor & 15.00 & 10 & 1.50 & 2.25 & 7.5 \\
Land use and eroded soil & 5.30 & 10 & 1.50 & 0.80 & 2.7 \\
Rural roads & 0.50 & 50 & 1.50 & 0.38 & 1.3 \\
Plantation forest & 2.70 & 10 & 1.00 & 0.27 & 0.9 \\
Reservoirs & 0.20 & 100 & 1.00 & 0.20 & 0.7 \\
Railways & 0.03 & 50 & 1.50 & 0.02 & 0.1 \\
Totals (where applicable) & 81.83 & & & 30.11 & \\
\hline
\end{tabular}

Source: Reference [59] (p. 12).

This being said, we are facing an ever-increasing loss of biodiversity. Every hour, 3 species disappear from the face of the earth. Every day, at least 72 species are lost. But the process of extinction has always been going on as a natural process, with no human involvement. This natural extinction process is estimated at about one out of a million species per year. And how many species are there on the planet? "Current estimates of the number of species can vary from, let's say, two million species to over 30 or even 100 million species," is how Dr. Braulio Dias, Executive Secretary of the Convention on Biological Diversity describes the problem [60]. Based on sequenation and comparison of the DNA of microorganisms, some studies estimate the number of species on our planet to be approximately 1 trillion. However, this increase in the estimated number of species has occurred only thanks to microorganisms [61].

It can be easily noted that the rate of extinction will be 262 species out of one million per year even if we take the highest estimate, which is definitely above the natural norm.

And, at the same time, humans have created about one billion technetic species-a lot more than the number of species created by nature [59]. Thus, technodiversity has not only surpassed biodiversity but is also suppressing it [62].

What underlies this growing burden on the environment? The existing economic paradigm of production and consumption which pushes the humanity to produce more, sell more, garner more profit and consume more. The technological progress can turn this aspiration towards augmenting production and consumption and depleting the Earth's resources into an extremely grave challenge. More precisely, the challenge certainly is not the progress in and of itself, but the use of technological achievements within the existing social structure, with accepted criteria of rationality which are unable to contain neither the growing disruption of the environmental balance nor the destructive interference into the human nature. All this is unfolding in the context of unrestrained pursuit of increasing the volume of consumed resources that turn into waste for the sake of ethereal satisfaction of false, illusory, simulative wants. In his recent Encyclical Letter "Fratelli tutti" (All Brothers), Pope Francis pointed out, "Often the voices raised in defense of the environment are silenced or ridiculed, using apparently reasonable arguments that are merely a screen for special interests. In this shallow, short-sighted culture that we have created, bereft of a shared vision, 'it is foreseeable that, once certain resources have been depleted, the scene will be set for new wars, albeit under the guise of noble claims'" [63]. He quoted his own words from the Encyclical Letter "Laudato Si" (Praise Be to You) [64] and further expressed his concern that the world "would be to plunge even more deeply into feverish consumerism and new forms of egotistic self-preservation" [63]. 


\section{Discussion}

Practical experience demonstrated the following: the so-called 'postindustrialism' that captured the minds of scholars around the globe in the end of the past century and in some cases, including in Russia, became the conceptual foundation for important political decisions is a chimera; and the so-called welfare state built exclusively on creativity, financialization, and hyperdevelopment of the service sector at the expense of material production cannot be sustainable.

Informatization (and in this day and age-digitalization) of social and economic processes and an increase in the significance of knowledge for production of the public product and the economy in general do not lead to the destruction of material production, but change its quality. New, budding material production, as we have already pointed out, augments its knowledge capacity, and the processes of its development and functioning become knowledge intensive. At the same time, since the 1950s, and particularly since the 1970s, the share of industrial product and of primary and secondary sectors in the GDP of individual countries and the world at large has actually been decreasing, whereas the share of the tertiary sector and services has been growing. That is how it looks on the surface. But what is the situation really like?

Supporters of postindustrial society concepts paid special attention precisely to a change in the share of industry and services sector in the GDP and the structure of employment. But they failed to explore the actual role and place of industry within the entire economic system and did not assess the extent to which technologies of the growing service sector were actually postindustrial (whereas they were largely preindustrial). While considering the important role of the knowledge economy and the development of information and telecommunications technologies, they overlooked all other trends, including the fact that industry is merely migrating from more developed to less developed countries and that the decrease in the share of the industrial sector in the GDP has been slowing down in the global economy in general since the beginning of the twenty first century and lately has been reversed $[65,66]$.

First, we counter postindustrialists by stating that an increase in the share of the service sector does not signify a decrease in the significance of material production in the economy, nor does it signal the transition to some postindustrial economy. Ultimately, services are also rendered on a material foundation. We see this as the manifestation of a different trend-a radical qualitative change in the nature of material production and an increase in the knowledge capacity of material production in general and of all its components (organization, means of production, technologies, materials, labor), in particular. Hence the growing influence of material production on societal development and expansion of its capabilities, as well as the demand to ensure high-tech reindustrialization and active progress down this path.

Second, is the 'postindustrial' type of development progressive?

Postindustrialists, who typically come from the 'Golden Billion' countries, generally believe it to be progressive. But the development of these countries is largely based not on their own domestic growth, but on the use of relatively cheap resources (natural, labor, intellectual) of developing countries which, therefore, find themselves in the position of perennial laggards. In terms of world-systems analysis as described by Immanuel Wallerstein [67], Andre Gunder Frank [68], and Samir Amin [69], the world is divided into the Core and the Periphery, where representatives of the former typically live at the expense of the latter [70]. Economic mechanism of this reallocation is based on financialization and domineering of the economy's financial segment over the real sector, which results in the distortion of price ratios and augmentation of unsecured trade and budget deficits of countries that are currently deemed 'developed'. Clearly, such development cannot be sustainable.

Multiple studies show that sustainable development and technological progress can be ensured only by domestic sources of growth generated in the industrial sector. Based on the endogenous growth theory [71-74], many economists, particularly Nicholas Kaldor 
and John Cornwall, pointed out that after the Industrial Revolution technological changes primarily occurred in industry. It is the expansion of the industrial sector that serves as an economic growth driver [75,76]. Moreover, John Cornwall [77] considered technological changes in some production sectors as drivers of efficiency growth in some other sectors.

As for the share of services in the economy, its increase has an opposite effect, as it slows down the pace of economic development. In 2008, a prominent Bangladeshi scholar Muyed Sultan conducted an extensive econometric study and used its results to make the following globally acknowledged and quantitatively proven conclusion, "Higher service share in the economy causes lower growth rate" [78] (p. 47). And we have been observing this lower growth for several decades. I would add that we are also witnessing disharmonization of the growth structure.

Technological progress ensures not only economic growth but also changes in the system of economic relations. What is the directionality of these changes? If we consider the aforementioned evolution of ownership relations from the perspective of its manifestations in the reality of sharing economy development, we can notice quite a few changes compared against the conventional economic order. Scholars of the sharing economy point out the transition to models of temporary access to goods and services in lieu of ownership, as well as broad application of modern IT technologies with the assistance of the Internet in order to gain such temporary access [17] (p. 1595).

The sharing economy is perceived as a transitional economic formation which combines both applied economic and non-economic motivations. New York University Professor Arun Sundararajan points out that any kind of sharing economy is characterized by an increased reliance on social rather than economic cues [79] (p. 27). Empirical studies performed on the basis of the already widespread sharing economy led to a similar conclusion on a combination of emotional and rational decision-making, individual interest-based, as well as prosocial motivations and monetary or nonmonetary stimuli [80] (p. 6).

What incentives and factors determine the current wide spread of the sharing economy?

All researchers, regardless of this scholarly affiliation, agree that consumers no longer want to purchase or own goods and products and seek ways to that would allow for temporary access. Participation in the sharing economy is determined by the fact that "people don't fundamentally want stuff. What they want is the stream of services that stuff provides over time" [81] (p. 391).

Thus, as we transition to the NIS.2, the system of ownership relations is undergoing dramatic changes, which brings about a change in the entire system of economic relations. The nature of the market is changing; an increasingly larger role is being played not by spontaneous market fluctuations, but by outcomes of complex coordinated actions between persons who hold various and intertwined elements of ownership rights. It is no coincidence that business circles and economy experts are now more and more actively discussing the concept of 'stakeholder capitalism', which reflects higher dependency of company operations on interests of various public groups, such as company employees, members of the local community, consumers, environmentalists, etc. At the World Economic Forum in Davos, representatives of 120 large corporations even developed the concept for measuring company participation in satisfying the interests of their stakeholders [82]. The nature of state regulation is also changing, as it will start to seek consensus in order to achieve a complicated balance of economic interests that stems from a new nature of ownership relations and a new type of market relations.

A major shift in public relations occurs also as a result of people being "squeezed out" of the production process by automated mechanisms and robots." This phenomenon is also based on the acceleration of scientific, technological and innovative development. As we transition to technologies with higher penetration level (in particular, communications, digital, cognitive technologies, etc.), the pace of such development is also increasing. We refer to this phenomenon of the current technological mode as the 'acceleration of acceleration'. It has become so prominent that the modern stage of the evolution that is based on acceleration of acceleration — evolution of the world as a whole and of individual 
countries-is more and more frequently determined as the Fourth Technological Revolution, according to Klaus Schwab's classification.

This technological revolution creates the premises for the NIS.2 and noonomy not only by shaping a new type of material production and transforming economic and social processes but also by changing the role of humans in traditional economic relations.

What kind of change are we talking about?

Robots and artificial intelligence are replacing the human workforce. Labor as a way of earning daily bread will gradually wash out of public production and cease to be a basic necessity. Workers involved in productive labor and, consequently, interacting under a special type of public relations, i.e., economic relations, will be replaced by man-made (for the time being) technetic beings. They can be more productive in their operations. They do not make mistakes and do not tire. They free up people's time for other activities and empower humans by creating premises for creative self-development. And they are replacing humans and human labor as a factor or element of production from immediate involvement in public production.

That brings up two points.

First, we must understand what people-not just as individuals, but as members of social groups-will do with this freedom. Will it do them good? Or will it lead to the escalation of conflicts and asocial actions?

Clearly, technological progress can have the effect of 'a monkey with a hand grenade' in an unprepared society. If we consider the biological aspect of the issue, then humans, out of all living beings, have proven to be the most destructive towards living nature. This leads to a major crisis in many areas: for example, biological crisis, or genomic crisis, when people can both interfere with their own nature and create creatures beyond their control—and much more.

It is clear that scientists who are pushing the horizons of scientific knowledge are driven by good intentions, such as the creation of new medicinal products and correction of genetic disorders. Still, they do not deny that these scientific achievements may very well be used to create new life forms and 'edit' humans' biological nature.

Exactly the same argument can be made regarding numerous modern technologies, for their careless and unlimited application can radically change our habitat, living conditions, and, ultimately, ourselves.

Is this path unreservedly positive? Or is it rife with fundamental danger for the humanity?

We need to recognize that under the existing economic rationality anything that yields economic profit is deemed possible and, further still, efficient. Indeed, the society imposes a number of limitations on the economy; otherwise, it would not have been able to function properly. But these bans and limitations, such as the ban on human, drug and arms trafficking or environmental regulations, are imposed onto economic relations exogenously and do not follow from the actual economic structure of the society. Existing economic relations create the foundation for the growing burden on the environment, interfering with human nature (not necessarily physical, for manipulations with human consciousness are equally as dangerous) and thoughtless expansion of consumption.

What are the immediate economic causes of this unchecked consumerism race that is gorging increasingly large volumes of natural resources? When a certain market segment is saturated, and people are essentially provided for (compared with the previous stage of development), what can be used to boost profit? Profit can be increased through market expansion. That can be achieved through innovations by offering completely new products and investing into their development (which tends to be the most costly and bears higher risks). Another option is to expand the market using an old product (which is usually cheaper and less risky) by capturing new markets through various means, including suppressing any competitors who may offer a better solution, but are weaker. The capital will seek to spend as little as possible and simultaneously absorb as many resources as 
possible. At the same time, it has no qualms about making profit using predatory methods. Such methods include imposing simulative goods on consumers.

Of course, we do not encounter purely false wants and purely simulative, useless goods all too often. False wants typically 'cling' to real wants, and the simulative component sort of envelops a product that satisfies real wants. Moreover, a product may initially be really useful and progressive, but then it acquires a simulative addition, and that is no longer progressive. All wars, including economic wars that are quite popular today, are also not progressive.

What trends will prevail? It depends on the correlation between the pace of two things: speed of production development and technical progress versus speed of humans ${ }^{\prime}$ cognizance of social consequences associated with the application of various technologies and structures for the satisfaction of human wants, the social superstructure. The social superstructure is changing, as well, but its changes follow after changes in material production. Yes, it affects material production by pushing it, and the emergent need makes people think-at first glance- that this superstructure comes first. But, in terms of establishing general social relations and changes, it is secondary and comes after material production.

\section{Conclusions}

The phrase about 'the modern world changing fast' has long since become commonplace. But daunting events related to the spread of the new coronavirus infection (COVID-19) made us reconsider this popular saying and reassess its meaning.

Indeed, we saw that changes in the application of technologies of the next technological mode were developing rather quickly both in the economy and the society.

At the same time, the image of post-pandemic future, which is already becoming our present-day reality, proves different from what many of us expected. That is why identification of special characteristics of the future now comes to the fore. But there is a lot more than needs to be done. An essential factor of our civilization's successful progress to the 'civilized' future is the adoption of a clearly humanitarian focus for social design that is used not only for predicting but also for creating the shape of the future society.

The world is not just changing fast, and the corona crisis is not a cause, but merely an accelerator of the processes and profound structural transformations of the economy and the society that could be discerned earlier, a long time before the pandemic. The modern social model, which is based on the economy as the main means for satisfying human wants, is currently exhibiting all signs of exhaustion and requires a change in the development paradigm.

As the recipient of the Nobel Prize in Economic Sciences Joseph Stiglitz pointed out in his interview for the Free Economic Society's Free Economy magazine published on the occasion of 2020 Moscow Academic Economic Forum, this model "leads to rather unpleasant phenomena-one thing that comes to mind is global inequality, which is only growing and broadening" [83]. We should pay attention to the close link between social and economic processes reflected in this quote.

Furthermore, achievements ensured by the current progress in science and technology allow for a dramatic decrease in conflictogenic factors in societal development, such as unequal access to amenities. Still, the existing economic model — that is based on market, property and profit-making as its main mission-not only prevents us from doing that but also increasingly promotes the escalation of this conflict. This is the core contradiction of the modern era in public development.

It is impossible to achieve harmony in public development, foster justice, balance out the interests of various social groups, promote humanitarian orientation of the society, etc., without changing the market model of the economy that underlies the current public order.

What are the premises for such changes? What is their main vector? And what should we do to ensure an anticipated, friendly and humane future, as opposed to some terrifying and indefinite prospects? 
Let us point out that, while further course of development seems unpredictable for some observers, the aforementioned specificity of the present situation follows from the entire prior evolution of the socioeconomic system.

What can be done to prepare humans for reasonable use of comforts offered by progress? Clearly, a special role in such preparation is assigned to the reproduction of qualities which qualify humans as social beings, e.g., as having social awareness, outlook and behavior. And, in this matter, the pivotal part is played by such phenomenon in human and societal development as culture in its broad sense, particularly such elements of culture as education and upbringing. It is necessary to facilitate the transition to a humanist society; otherwise, the fork in history engendered by the technological revolution will bring the humanity to a dead end and result in regress and degeneration.

Besides, we must admit that, according to the development scenario under consideration (let us point out-a rather realistic scenario, and we can already see signs of that), purely economic relations as relations between people in the process of public production are disappearing. That will create premises for the formation of a new type of society devoid of the economic foundation in its modern sense but still based on material production.

At the same time, it is hard to expect that the humanity will change quickly. That is a historically inevitable, but rather controversial process, even though cues of the social evolution in this direction can be observed throughout human history and today, as well. And we have pointed them out. But, due to a large number of contradictions surfacing in the modern world, the movement towards the NIS.2 and noonomy will be not conventionally linear, predetermined or incremental. In particular, we are currently seeing that global financial capital and corporations continue to shape and promote (in order to garner additional profits) the so-called simulative wants; put simply, simulative wants constitute unreasonable wants which in the process of their satisfaction consume increasingly large volumes of real resources while damaging the environment and maiming people's souls by prompting them to engage in asocial behaviors.

This economic model brings our civilization to a dead end and leads the socioeconomic system to discontinuity and destruction. That is why it is becoming urgent that we reject the acceleration of simulative consumption, as reflected in the internationally acknowledged Sustainable Development efforts supported by the UN.

But what should serve as the foundation for our finding a way out of this situation, with the need to resolve it already pushing its way onto the current agenda?

It would have to involve the transition to reasonable management of the economy-to the noostage. At this stage, nooproduction that operates in the autonomous technosphere and is detached from humans and the society will still have its goals and objectives subjugated to public interest. The development of the noosociety and the transition to nooproduction and nooneeds will be accompanied by the transition from economic rationality to a new one, and this new nature of rationality and, accordingly, a new definition of development goals will gain paramount importance and serve as the basis for changing the nature of public relations.

Thus, the economy will be replaced by the noonomy. The noonomy relies on a noneconomic way of satisfying human wants which will be shaped through a new quality of production wherein people will-according to Marx's prediction-"step to the side of the production process".

Let us emphasize that the genesis of the noonomy is an objective process, but, clearly, it can have various forms of social organization, some adequate to its content, others not quite. The study if these forms and institutions is an important separate topic that lies outside the subject field of this text. Still, in this article we feel compelled to emphasize that the nature of these changes must be evolutionary, and they should organically grow out of the public conditions formed at a given moment of 'social time' and in the given 'social space'. As the historical experience of the twentieth century indicates, Lenin's model of revolutionary impact executed by the political avant-garde cannot ensure adequate 
conditions for the development of objective processes pertaining to the maturation of prerequisites and elements of a qualitatively new society.

The transition towards the noonomy is a long and controversial process rife with a wide range of problems of the modern socioeconomic order, including profound technological, socioeconomic and cultural differences by country and between various social strata. Many global issues, in particular poverty and the fact that a significant share of the global population has limited access to development resources (including not only access to a rather high income level but also access to quality lifelong education, healthcare services, culture, and, most importantly, meaningful labor), follow directly from the economic mechanism for wants satisfaction. As these issues persist, they simultaneously create the premises and major barriers for progress towards the noonomy. Overcoming these barriers is a major practical task and theoretical problem that the author has already addressed in his Russian publications and intends to consider in his upcoming English publications, but it is not feasible to pay special attention to this matter herein.

There have been recurrent questions about the term 'noonomy', which is often interpreted quite superficially as the combination of 'noosphere' and 'economy'. Such interpretations, as any scientific point of view, definitely have the right to exist, but when we speak of 'noonomy', we imply a completely different meaning. Our understanding of noonomy is much broader and deeper. The term 'noonomy' derives from Greek words

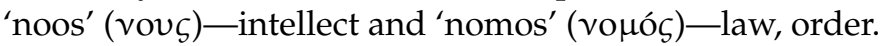

Thus, we do not employ a mechanical combination of the terms 'noosphere' and 'economy', but draw on the Greek term 'noos' in the following meaning: 'intellect reliant on the criterion basis of truth as a perceived timeless value'. In this sense, it is a big mistake to reduce the Greek 'noos' to its Latin counterpart 'ratio'.

'Rational' means conforming to certain criteria (but are these criteria reasonable in and of themselves?). The economy is always rational, but are actions of rationally operating economic agents necessarily reasonable? Can they transcend the limits of criteria that are imposed by the current economic system?

The noonomy stipulates a different method for assessing economic actions and a different method for assessing wants that is based not on rationality, but on reason, i.e., on 'noo' that stems from understanding true consequences of economic decisions and true value of satisfied wants. Thus, we are not talking about the economy or individuals who are rationally maximizing their pleasures, but about a different method for the formation and satisfaction of wants that can be referred to as noowants. At some point, e.g., under the gathering society, humans satisfied their wants without any economic calculations. The noonomy also constitutes a non-economic way of wants satisfaction which will be formed at a new stage in the development of human knowledge and technologies.

On the other hand, the second part of the term 'noonomy' (derived from the Greek 'nomos', or 'law, order') is an ancient concept used by philosophers in the first third of the twentieth century to signify the basic principle for organizing any space [84], an absolute law that governs the existence of all things. Thus, the noonomy constitutes a structured paradigm, a method for the satisfaction of wants under the society which: has "the light of knowledge"; wherein there are no relations to production and no production relations; which has no relations to possessions and no ownership relations; and wherein there is no economy, and the economy is impossible. The noonomy stands for non-economic satisfaction of noowants.

It is important that on this evolutionary path (its main points of reference identified here) we not stultify or forget the main goal that has already been mentionedcomprehensive facilitation of human development. Civilizational development makes no sense in the absence of humanitarian content. Indeed, socioeconomic relations transform and change, but the ultimate goal of these processes should be the progress of human qualities, humans' self-development and self-elevation so as to ensure that homines economici complete their historic mission and transform into 'noohumans' governed not by calculated self-interest but by humanism. 
Funding: This research received no external funding.

Institutional Review Board Statement: Ethical review and approval were waived for this study, due to the study not involving humans or animals.

Informed Consent Statement: Not applicable.

Data Availability Statement: No new data were created or analyzed in this study. Data sharing is not applicable to this article.

Conflicts of Interest: The author declares no conflict of interest.

\section{References}

1. Bell, D. The Coming of Post-Industrial Society: A Venture in Social Forecasting; Basic Books: New York, NY, USA, 1973.

2. Toffler, A. The Third Wave; Pan Books Ltd. in Association with William Collins Sons \& Co. Ltd.: London, UK, 1980.

3. Sakaiya, T. The Knowledge-Value Revolution or A History of the Future; Kodansha International: Tokyo, Japan; New York, NY, USA, 1991.

4. Heilbroner, R. Economic Problems of "Postindustrial” Society. In Dimensions of Society; Potter, D., Sarre, P., Eds.; University of London Press Ltd.: London, UK, 1974.

5. Heilbroner, R. Business Civilization in Decline; Norton: New York, NY, USA, 1976.

6. Gibson, D. Post-Industrialism: Prosperity or Decline? Sociol. Focus 1993, 26, 147-163. [CrossRef]

7. Smart, B. (Ed.) Post Industrial Society; SAGE Publications Ltd.: London, UK, 2011.

8. Schumpeter, J.S. Business Cycles: A Theoretical, Historical and Statistical Analysis of the Capitalist Process; McGraw-Hill: New York, NY, USA, 1939; Volume I.

9. Mensch, G. Das Technologische Patt: Innovationen Überwinden Die Depression; Umschau Verlag Breidenstein: Frankfurt, Germany, 1975.

10. Perez, C. Structural Change and Assimilation of New Technologies in The Economic and Social Systems. Futures 1983, 15, 357-375. [CrossRef]

11. Perez, C. Technological Revolutions and Financial Capital: The Dynamics of Bubbles and Golden Ages; Elgar: London, UK, 2002.

12. Freeman, C.; Perez, C. Structural Crises of Adjustment, Business Cycles and Investment Behaviour. In Technical Change and Economic Theory; Dosi, G., Freeman, C., Nelson, R., Silverberg, G., Soete, L., Eds.; Pinter Publisher: London, UK, 1988.

13. L'vov, D.S.; Glaz'ev, S.Y. Teoreticheskie i prikladnye aspekty upravleniia NTP. Theoretical and Applied Aspects of Managing Scientific Progress. Econ. Math. Methods 1986, 5. [CrossRef]

14. Schwab, K. The Fourth Industrial Revolution; Portfolio Penguin: London, UK, 2017.

15. Bodrunov, S.D. Novoe industrial'noe obshchestvo. Proizvodstvo. Ekonomika. Instituty (New industrial Society. Production. Economy. Institutions). Econ. Revival Russ. 2016, 2, 5-14.

16. Benkler, Y. 'Sharing Nicely': On Shareable Goods and the Emergence of Sharing as a Modality of Economic Production. Yale Law J. 2004, 114, 273-358. [CrossRef]

17. Belk, R. Sharing. J. Consum. Res. 2010, 36, 715-734. [CrossRef]

18. Bodrunov, S.D. Griadushchee. Novoe industrial'noe obshchestvo: Perezagruzka [The Coming of New Industrial Society: Reloaded], 2nd ed.; S. Y. Witte Institute for New Industrial Development: St. Petersburg, Russia, 2016.

19. Veblen, T. The Theory of the Leisure Class: An. Economic Study of Institutions; The Macmillan Company: New York, NY, USA, 1899.

20. Baudrillard, J. Pour Une Critique Di L'economie Politique Du Signe; Editions Gallimatd: Paris, France, 1972.

21. Baudrillard, J. Simulacres Et Simulation; Editions Galilee: Paris, France, 1981.

22. Jameson, F. Postmodernism or the Cultural Logic. of Late Capitalism; Duke University Press: Durham, NC, USA, 1991.

23. Earth Overshoot Day. Global Footprint Network. Available online: https://www.footprintnetwork.org/our-work/earthovershoot-day/ (accessed on 9 November 2020).

24. Bodrunov, S.D. Noonomika [Noonomy]; Kul'turnaya revoliutsiia: Moscow, Russia, 2018.

25. Haraguchi, N.; Fang, C.; Cheng, C.; Smeets, E. The Importance of Manufacturing in Economic Development: Has This Changed? World Dev. 2017, 93, 293-315. [CrossRef]

26. Herman, E. The Importance of the Manufacturing Sector in the Romanian Economy. Procedia Technol. 2016, 22, 976-983. [CrossRef]

27. Jeon, Y. Manufacturing, Increasing returns and economic development in China, 1979-2004: A Kaldorian Approach. University of Uta Department of Economics Working Paper Series, Working Paper 2008, No. 2006-2008. Available online: https:/ / economics. utah.edu/research/publications/2006_08.pdf (accessed on 9 November 2020).

28. Dasgupta, S.; Singh, A. Will Services Be the New Engine of Economic Growth in India? Working Papers; University of Cambridge: Cambridge, UK, 2005.

29. Loto, M.A. Global Economic Downturn and the Manufacturing Sector Performance in the Nigerian Economy (A Quarterly Empirical Analysis). J. Emerg. Trends Econ. Manag. Sci. 2012, 3, 38-45.

30. Collins, M. Debunking the Post-Industrial Myth. Industrial Week, 22 November 2015. Available online: https:// www.industryweek.com/the-economy/public-policy/article/22007271/debunking-the-postindustrial-myth(accessed on 9 November 2020). 
31. Stehrer, R.; Baker, P.; Foster-McGregor, N.; Koenen, J.; Leitner, S.; Schricker, J.; Strobel, T.; Vieweg, H.-G.; Vermeulen, J.; Yagafarova, A. Study on the Relation between Industry and Services in Terms of Productivity and Value Creation; Study for the Directorate-General for Enterprise and Industry. (Within the Framework Contract for Industrial Competitiveness and Market Performance-ENTR/90/PP/2011/FC); ECSIP Consortium: Vienna, Austria, 30 October 2014. Available online: https://ec. europa.eu/docsroom/documents/8528/attachments/1/translations/en/renditions/native (accessed on 9 November 2020).

32. Behun, M.; Gavurova, B.; Tkacova, A.; Kotaskova, A. The Impact of the Manufacturing Industry on the Economic Cycle of European Union Countries. J. Compet. 2018, 10, 23-39. [CrossRef]

33. McKinsey. Manufacturing the Future: The Next Era of Global Growth and Innovation. McKinsey Global Institute Report. 2012. Available online: https://www.mckinsey.com/ \{\}/media/McKinsey/Business\%20Functions/Operations/Our\% 20Insights/The\%20future\%20of\%20manufacturing/MGI_\%20Manufacturing_Full\%20report_Nov\%202012.pdf (accessed on 9 November 2020).

34. Naudé, W.; Szirmai, A. The Importance of Manufacturing in Economic Development: Past, Present and Future Perspectives; UNU-MERIT Working Papers; UNU-MERIT: Maastricht, The Netherlands, 2012.

35. Westkämper, E. Towards the Re-Industrialization of Europe: A Concept for Manufacturing for 2030; Springer: Berlin/Heidelberg, Germany, 2014. [CrossRef]

36. Building a Strong and Modern European Industry. Business Europe. June 2017. Available online: https://www.businesseurope. eu/sites/buseur/files/media/reports_and_studies/building_a_strong_and_modern_european_industry_-_compressed_for_ web_and_sending.pdf (accessed on 9 November 2020).

37. Industrie 4.0-Germany Market Report and Outlook. Germany Trade \& Invest (GTAI). 27 March 2018. Available online: https: / / www.gtai.de/resource/blob/64500/8b7afcaa0cce1ebd42b178b4430edc82/industrie4-0-germany-market-outlookprogress-report-en-data.pdf (accessed on 9 November 2020).

38. Boyes, H.; Hallaq, B.; Cunningham, J.; Watson, T. The industrial internet of things (IIoT): An analysis framework. Comput. Ind. 2018, 101, 1-12. [CrossRef]

39. Jiménez, M.; Romero, L.; Dominguez, I.A.; del Mar Espinosa, M.; Dominguez, M. Additive Manufacturing Technologies: An Overview about 3D Printing Methods and Future Prospects. Hindawi Complex. 2019. [CrossRef]

40. Adams, S. Half Million 3d Printers sold in 2017-On Track for $100 \mathrm{~m}$ Sold in 2030. 3D Printing Industry. 6 April 2018. Available online: https:/ /3dprintingindustry.com/news/half-million-3d-printers-sold-2017-track-100m-sold-2030-131642/(accessed on 9 November 2020).

41. Greenwood, M. 2018 Was a Strong Year for the Global 3D Printer Market. Available online: https://www.engineering com/AdvancedManufacturing/ArticleID/18279/2018-Was-a-Strong-Year-for-the-Global-3D-Printer-Market.aspx (accessed on 9 November 2020).

42. Bainbridge, W.S.; Roco, M.S. (Eds.) Managing Nano-Bio-Infocogno Innovations: Converging Technologies in Society; National Science Foundation, National Science and Technology Council's Subcommittee on Nanoscale Science, Engineering, and Technology; Springer: Dordrecht, The Netherlands, 2006. [CrossRef]

43. Spohrer, J. NBICS (Nano-Bio-Info-Cogno-Socio) Convergence to Improve Human Performance: Opportunities and Challenges. In Converging Technologies for Improving Human Performance: Nanotechnology, Biotechnology, Information Technology and Cognitive Science; Roco, M., Bainbridge, W., Eds.; National Science Foundation: Arlington, VA, USA, 2002; pp. 101-116. Available online: https://iphras.ru/uplfile/Vladimir_Burov/nbic_report.pdf (accessed on 9 November 2020).

44. Of Moonshots and Shuttles. Local Motors. Available online: https://localmotors.com/meet-olli/ (accessed on 9 November 2020).

45. Tess. Local Motors' Self-driving 'Olli' Shuttle Helped Along by Makerbot 3D Printers. 3D Printer and 3D Printing News, 30 August 2017. Available online: http:/ / www.3ders.org/articles/20170830-local-motors-self-driving-olli-shuttle-helped-alongby-makerbot-3d-printers.html(accessed on 9 November 2020).

46. Local Motors Debuts "Olli", the First Self-Driving Vehicle to Tap the Power of IBM Watson. IBM, 16 June 2016. Available online: https://www-03.ibm.com/press/us/en/pressrelease/49957.wss(accessed on 9 November 2020).

47. Tsvetkova, M.; Yasseri, T.; Meyer, E.T.; Pickering, J.B.; Engen, V.; Walland, P.; Luders, M.; Følstad, A.; Bravos, G. Understanding Human-Machine Networks: A Cross-Disciplinary Survey. arXiv 2017, arXiv:1511.05324v1. [CrossRef]

48. Galbraith, J.K. The New Industrial State; Houghton Mifflin Co.: Boston, MA, USA, 1967.

49. Bodrunov, S.D. New Industrial Production of the Second Generation. In Materials for the International Seminar on Conceptualising of Economic Development and Cooperation in Eurasia, Cambridge, 02 May 2016, Scientific Papers of S.Y. Witte Institute for New Industrial Development (INID); S.Y. Witte INID: St. Petersburg, Russia, 2016.

50. Bodrunov, S.D.; Galbraith, J.K. New Industrial Revolution and Inequality Issues: Study Guide; Plekhanov Russian University of Economics: Moscow, Russia, 2017.

51. Richter, F. The Rise of the Sharing Economy. Statista, 3 June 2014. Available online: https://www.statista.com/chart/2323/therise-of-the-sharing-economy / (accessed on 9 November 2020).

52. Number of Car Sharing Users Worldwide from 2006 to 2025. Statista Research Department. August 2016. Available online: https:/ / www.statista.com/statistics/415636/car-sharing-number-of-users-worldwide/ (accessed on 9 November 2020).

53. Svegander, M. The Carsharing Telematics Market-3rd Edition. Product Sheet. Berg Insight. M2M Research Series. 2019. Available online: http:/ / www.berginsight.com/ReportPDF/ProductSheet/bi-carsharing3-ps.pdf (accessed on 9 November 2020). 
54. The Carsharing Telematics Market-2nd Edition. Summary. Berg Insight. M2M Research Series. 2018. Available online: http:/ / www.berginsight.com/ReportPDF/Summary/bi-carsharing2-sum.pdf (accessed on 9 November 2020).

55. Shaheen, S.; Cohen, A.; Jaffee, M. Innovative Mobility: Carsharing Outlook 2018. Berkley University of California. Institute of Transportation Studies at UC Berkeley, UC Berkeley Transportation Sustainability Research Center. Available online: https: / / escholarship.org/uc/item/49j961wb (accessed on 9 November 2020).

56. ina Sharing Economy Market to Exceed 9 Trln Yuan: Report. Xinhua, 11 February 2019. Available online: http://www.xinhuanet. com/english/2019-11/02/c_138523206.htm(accessed on 9 November 2020).

57. Wallenstein, J.; Shelat, U. Hopping Aboard the Sharing Economy. The Boston Consulting Group, Henderson Institute. 22 August 2017. Available online: http://image-src.bcg.com/Images/BCG-Hopping-Aboard-the-Sharing-Economy-Aug-2017_tcm104-1 68558.pdf (accessed on 9 November 2020).

58. Bardhi, F.; Eckhardt, G.M. Access based consumption: The case of car sharing. J. Consum. Res. 2012, 39, 881-898. [CrossRef]

59. Zalasiewicz, J.; Williams, M.; Waters, C.N.; Barnosky, A.D.; Palmesino, J.; Rönnskog, A.-S.; Edgeworth, M.; Neal, C.; Cearreta, A.; Ellis, E.C.; et al. Scale and diversity of the physical technosphere: A geological perspective. Antropocene Rev. 2016, 4, 9-22. [CrossRef]

60. Knight, R. Biodiversity Loss: How Accurate Are the Numbers? BBC News, 24 April 2012. Available online: https://www.bbc. $\mathrm{com} /$ news / magazine-17826898(accessed on 9 November 2020).

61. Locey, K.J.; Lennon, J.T. Scaling laws predict global microbial diversity. Proc. Natl. Acad. Sci. USA 2016, 21, 5970-5975. Available online: https: / / www.pnas.org/content/113/21/5970 (accessed on 9 November 2020). [CrossRef] [PubMed]

62. UN Report: Nature's Dangerous Decline ‘Unprecedented'; Species Extinction Rates 'Accelerating'. 6 May 2019. Available online: https://www.un.org/sustainabledevelopment/blog/2019/05/nature-decline-unprecedented-report/ (accessed on 9 November 2020).

63. Francis, I. "Fratelli Tutti." The Holy See. Available online: http://www.vatican.va/content/francesco/en/encyclicals/ documents/papa-francesco_20201003_enciclica-fratelli-tutti.html (accessed on 9 November 2020).

64. Francis, I. “Laudato Si.” The Holy See. Available online: http://www.vatican.va/content/francesco/en/encyclicals/documents / papa-francesco_20150524_enciclica-laudato-si.html (accessed on 9 November 2020).

65. Share of Economic Sectors in the Global Gross Domestic Product (GDP) from 2008 to 2018. Statist, 29 July 2020. Available online: https: / / www.statista.com/statistics / 256563/share-of-economic-sectors-in-the-global-gross-domestic-product/\#: \{\{\}: text=This \%20statistic\%20shows\%20the\%20share,See\%20global\%20GDP\%20for\%20comparison(accessed on 9 November 2020).

66. Industry (Including Construction), Value Added (\% of GDP) 1996-2019. World Bank National Accounts Data, and OECD National Accounts Data Files. Available online: https:/ / data.worldbank.org/indicator/NV.IND.TOTL.ZS?end=2019\&start=1996 (accessed on 9 November 2020).

67. Wallerstein, I. World-Systems Analysis. Social Theory Today; Polity Press: Cambridge, UK, 1987.

68. Frank, A.G. Dependent Accumulation and Underdevelopment; Monthly Review Press: New York, NY, USA, 1963.

69. Amin, S. Capitalism in an Age of Globalization; Zed Books: London, UK, 1997.

70. Prebisch, R. Capitalismo Periferico: Crisis Y Transformacion; Fondo de Cultura Economica: Mexico City, Mexico, 1981.

71. Aghion, P.; Howitt, P. Endogenous Growth Theory; MIT Press: Cambridge, MA, USA, 1998.

72. Lucas, R.E., Jr. On the mechanics of economic development. J. Monet. Econ. 1988, 22, 3-42. [CrossRef]

73. Romer, P.M. Increasing returns and long-run growth. J. Political Econ. 1986, 94, 1002-1037. [CrossRef]

74. Romer, P.M. Endogenous technological change. J. Political Econ. 1990, 98, 71-102. [CrossRef]

75. Kaldor, N. The case for regional policies. Scott. J. Political Econ. 1970, XVII, 337-348. [CrossRef]

76. Cornwall, J. Modern Capitalism. Its Growth and Transformation; St. Martin's Press: New York, NY, USA, 1977.

77. Cornwall, J. Diffusion, convergence and Kaldor's laws. Econ. J. 1976, 86, 307-314. [CrossRef]

78. Sultan, M. The Tertiary Sector Is Going to Dominate the World Economy; Should We Worry? MPRA Paper \#14681. 2008. Available online: https:/ / core.ac.uk/download/pdf/213908608.pdf (accessed on 9 November 2020).

79. Sundararajan, A. The Sharing Economy. The End of Employment and the Rise of Crowd-Based Capitalism; MIT Press: Cambridge, MA, USA, 2016.

80. Torrent-Sellens, J. Collaborative Behavior and the Sharing Economy: Pan-European Evidence for a New Economic Approach. In Strategy and Behaviors in the Digital Economy; Orlando, B., Ed.; IntechOpen: London, UK, 2018.

81. Munger, M.C. Tomorrow 3.0: The Sharing Economy. Indep. Rev. 2016, 20. Available online: http://www.independent.org/pdf/ tir/tir_20_03_11_munger.pdf (accessed on 9 November 2020). [CrossRef]

82. Measuring Stakeholder Capitalism: Towards Common Metrics and Consistent Reporting of Sustainable Value Creation. 22 September 2020. Available online: https:/ / www.weforum.org/reports/measuring-stakeholder-capitalism-towards-commonmetrics-and-consistent-reporting-of-sustainable-value-creation (accessed on 9 November 2020).

83. Stiglitz, J. Ia ne vizhu, chto na ekonomiku nadvigaetsia krizis [I Do Not See That the Economy Is Nearing a Crisis]. Free Economy, 23 March 2020. Available online: http:/ / freeconomy.ru/intervyu/dzhozef-stiglits-ya-ne-vizhu-chto-na-ekonomikunadvigaetsya-krizis.html(accessed on 9 November 2020).

84. Schmitt, C. Der Nomos Der Erde Im Völkerrecht Des Jus Publicum Europaeum; Duncker \& Humblot: Berlin, Germany, 1950. 